\title{
Evaluating The Relationship Between Spatial Temporal Land Use Changes And Climate Pattern Of Nilgiris District
}

\author{
M.Suguna Devakumari*, S. Carolin Jeeva, R.Susan Poonguzhali \\ *Assistant Professor \\ Department of Agriculture \\ School of Agriculture and Biosciences \\ Karunya Institute of Technology and Sciences, Coimbatore 641114
}

\begin{abstract}
Due to deforestation, urbanization and land use changes, the Nilgiris district of Tamil Nadu has been impacted by climate variation. This study was carried out to explore the impact of the land use changes in Nilgiris District from 2011 to 2017using remote sensing images acquired from Landsat 7. Temperature and rainfall data of the study area were also obtained from IMD Pune. The results show that the current trend of decreasing forest area and increasing agricultural land, and the area also experienced a temperature increase of $0.4{ }^{\circ} \mathrm{C}$ between 2011 and 2017. This study is crucial for land planners and environmentalists to understand the impacts of land use change on the climate in Nilgiris District.
\end{abstract}

\section{KEY WORDS}

Land use, Climate change, Forest, Fallow, Agriculture area

*Corresponding Author, Email ID: sugisathish@yahoo.com 


\section{INTRODUCTION}

With rapid social and economic development, the influence of human activities on the land use changes have been intensified. Land use changes convey the intensity of human activities and can provide a basis for discussing the relationship between land-use and environmental changes [Mishraa et al, 2010].

The impacts of land use and climate change are set to increase in the future due to the increased clearance of virgin forest lands for agriculture and the rise of global warming.

Land use change, in the form of clearance for crops and pasture, affects net radiation and the partitioning of available energy at the surface. Since conversion of native vegetation to crops and pasture typically increases albedo, it reduces net radiation (Forster et al., 2007).

Deforestation is one of the main purposes for global warming and contributor of greenhouse effect. In recent years, Remote Sensing and Geographical Information System have the prospective to deliver precise information regarding terrestrial use and forest surface changes. The current analysis assesses the usefulness of high resolution satellite data for analysing the change of terrestrial use and forest surface change of Nilgiris district for 2011-2017. The Landsat imageries of 2011 to 2017 were analysed using software. The comprehensive study has revealed that the region under forest has decreased, agricultural area has increased and fallow land decreased from $182.3 \mathrm{~km}^{2}$ to $110.3 \mathrm{~km}^{2}$. There has been a vast change in the strategy of forest surface and terrestrial usage throughout the region of Nilgiris.

This paper analyses the relationship between forests, agricultural land, temperature and rainfall. The quantity of rain that falls in the humid tropics depends on several factors, of which forest cover appears to be one. Other rain-causing phenomena include geographic location, topographic features, sea-surface temperature and land temperature, together with other forms of vegetation cover.

Shukla and Mintz (1981) report that modifications in vegetation cover due to the deforestation of large-magnitude areas surely influence precipitation. The hypothesis is based on correlation between precipitation and evapotranspiration. The determinant factor is not only the vegetation but also the relationship between the moisture content of soil, vegetation and the solar energy necessary for transforming water into atmospheric water vapour. 
Finally there is the role of cloud forests, mossy forests and stunted woodlands occurring in the tropical montane belts and along coastal fog zones. This role should be emphasized in harnessing the moisture from the clouds through the mechanism of cloud or fog stripping (Stadtmuller, 1986). Even a single tree or a group of trees can trap a substantial quantity of rainwater through the process called horizontal precipitation (Zadroga, 1981).

Dickinson (1980) states that none of the numerical studies reviewed by him has treated the effect of deforestation on increasing temporal and spatial fluctuations between wet and dry conditions. However, he feels that such a change in surface conditions could in turn increase the intensity and decrease the duration of tropical rainfall, enhancing run-off even if the mean rainfall were unchanged.

\section{MATERIALS AND METHODS}

The study area is the Nilgiris district is situated at an elevation of 900 to 2636 meters above MSL. Its latitudinal and longitudinal dimensions being $130 \mathrm{KM}$ (Latitude: 10 - 38 WP 11-49N) by $185 \mathrm{KM}$ (Longitude: $76.0 \mathrm{E}$ to $77.15 \mathrm{E}$ ).

Cloud free Landsat-TM satellite imageries were used to assess the Land use changes for the years 2011 to 2017. The Data Product used was landsat-7-ETm+. The Resolution of the cell size was $(\mathrm{x}, \mathrm{y})=30,30$. The Path/row utilized was path -144 and row -52 respectively. The Number of bands used were 6 (b1, b2, b3, b4, b5, b7). The standard methods of visual interpretation techniques have been employed for the interpretation, classification and delineation of land use categories based on tone, texture, shape, size, pattern and differential erosion characteristics of the satellite imagery.

\section{Figure 1 Satellite images of land use classification of Nilgiris (2011, 2013, 2015 \&2017)}
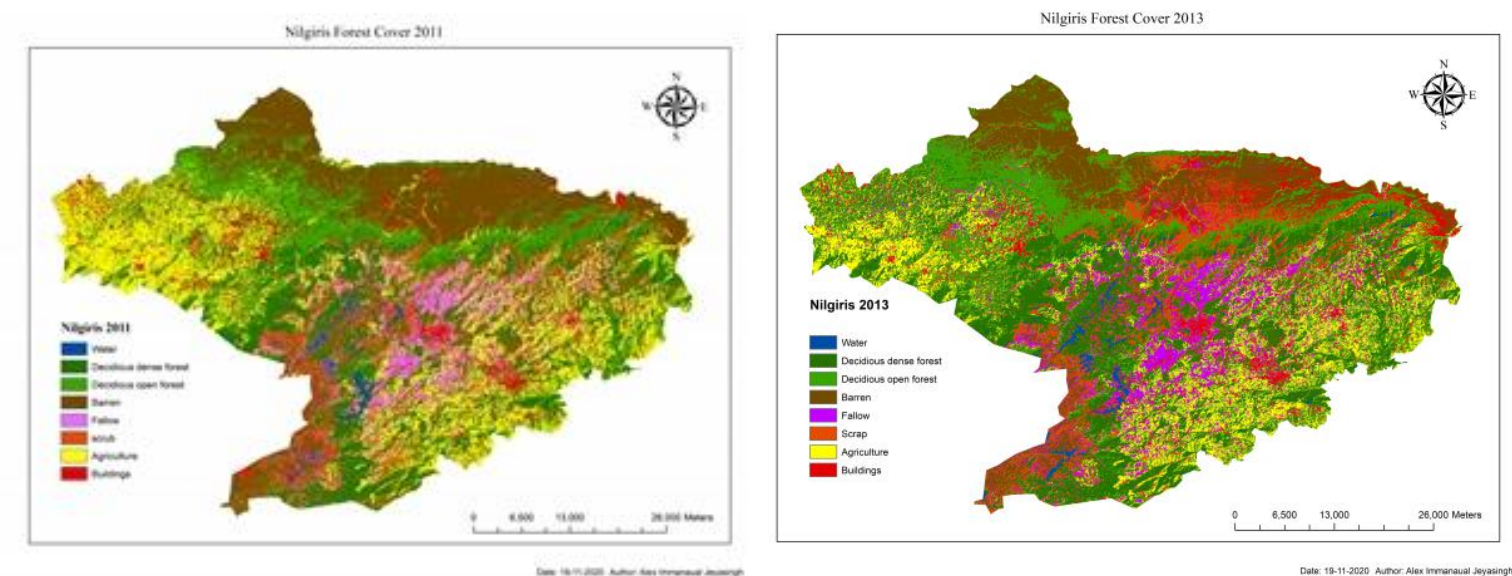

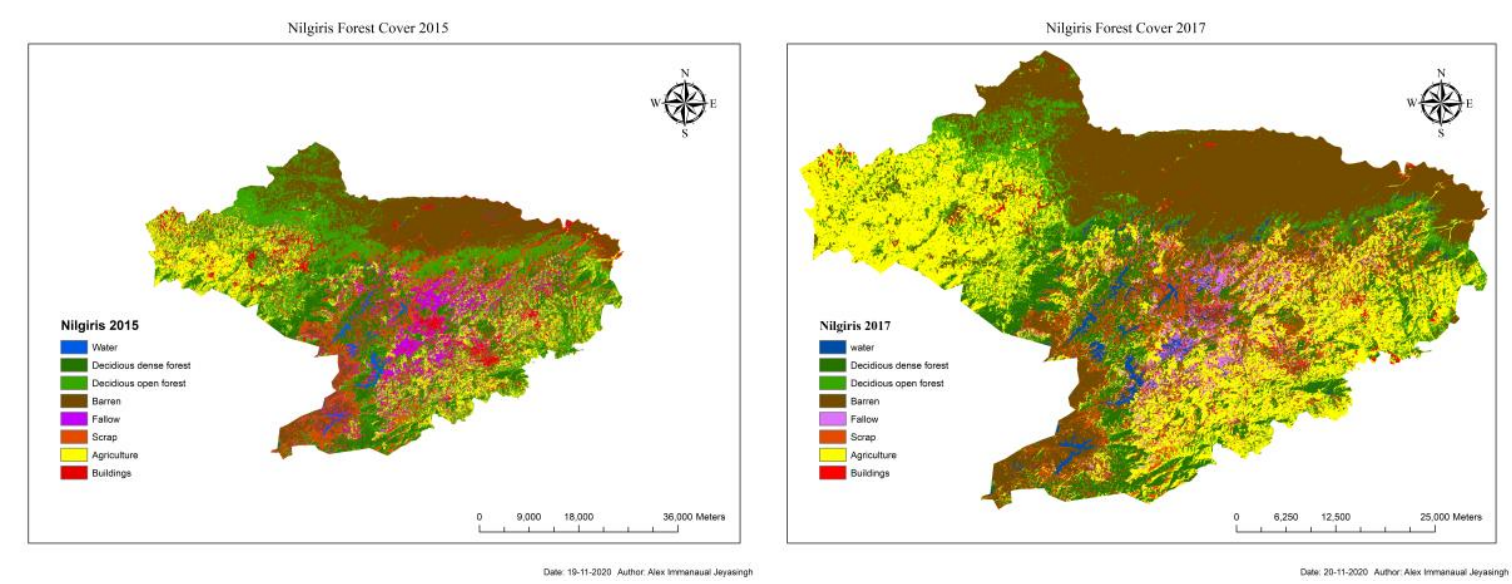

The detection of changes from initial status of 2011 to final situation of 2017 was reported to get an exact idea about how much alteration has taken place in different land use categories viz, forest, agriculture and fallow during the study period.

In achieving this, the first task was to develop a table showing the area in $\mathrm{km}^{2}$. In obtaining percent change, the area $\left(\mathrm{km}^{2}\right)$ is converted to percentage and the difference is calculated for the duration 2011 to 2017 . The rate of change of the area of forest, agriculture, fallow with respect to climatic factors viz., rainfall and temperature was expressed for 2011 to 2017. The trend of forest area vs rainfall and temperature, fallow area vs rainfall and temperature, agricultural area vs rainfall and temperature from 2011 to 2017 was estimated and predicted.

\section{RESULTS AND DISCUSSION}

Land use maps from Landsat imageries of 2011 to 2017 were produced and percent change of land use was carried out.

Table 1 Land use pattern in the Nilgiris district from 2011 to 2017

\begin{tabular}{|l|l|l|l|l|l|l|}
\hline Year & $\begin{array}{l}\text { Forest area } \\
\left(\mathrm{km}^{2}\right)\end{array}$ & Area $(\%)$ & Fallow area $\left(\mathrm{km}^{2}\right)$ & Area $(\%)$ & $\begin{array}{l}\text { Agriculture } \\
\text { area }\left(\mathrm{km}^{2}\right)\end{array}$ & Area $(\%)$ \\
\hline 2011 & 1634 & 64 & 182.3 & 7.1 & 526.9 & 20.7 \\
\hline 2013 & 1463 & 57.4 & 226 & 8.6 & 382.3 & 14.9 \\
\hline 2015 & 1197 & 46.9 & 171.5 & 6.7 & 402.4 & 15.8 \\
\hline 2017 & 1048 & 41.1 & 110.3 & 4.3 & 532.5 & 20.8 \\
\hline & & & & $\begin{array}{l}\text { Total } \\
\text { area }\end{array}$ & 2549 & \\
\hline
\end{tabular}


Table 2 Percent change in land use pattern form 2011 to 2017

\begin{tabular}{|l|l|l|l|l|l|}
\hline & $\begin{array}{l}\mathbf{2 0 1 1} \text { Area } \\
(\mathbf{k m 2})\end{array}$ & $\begin{array}{l}\text { Area in } \\
\text { \% }\end{array}$ & 2017 Area $(\mathbf{k m 2})$ & $\begin{array}{l}\text { Area in } \\
\text { \% }\end{array}$ & $\begin{array}{l}\text { \% } \\
\text { change }\end{array}$ \\
\hline FOREST & 1634 & 64 & 1048 & 41.1 & -22.9 \\
\hline FALLOW & 182.3 & 7.1 & 110.3 & 4.3 & -2.8 \\
\hline AGRICULTURE & 526.9 & 20.7 & 532.4 & 20.8 & 0.2 \\
\hline
\end{tabular}

The forest area and the fallow land found to be decreased by $22.9 \%$ and $2.8 \%$ respectively whereas the agriculture land increased by $0.2 \%$. Forest area, which was spread over $1634 \mathrm{~km}^{2}$ area in 2011, degraded to only $1048 \mathrm{~km}^{2}$ in 2017.

Figure 2 Graph of trend analysis of the land use class

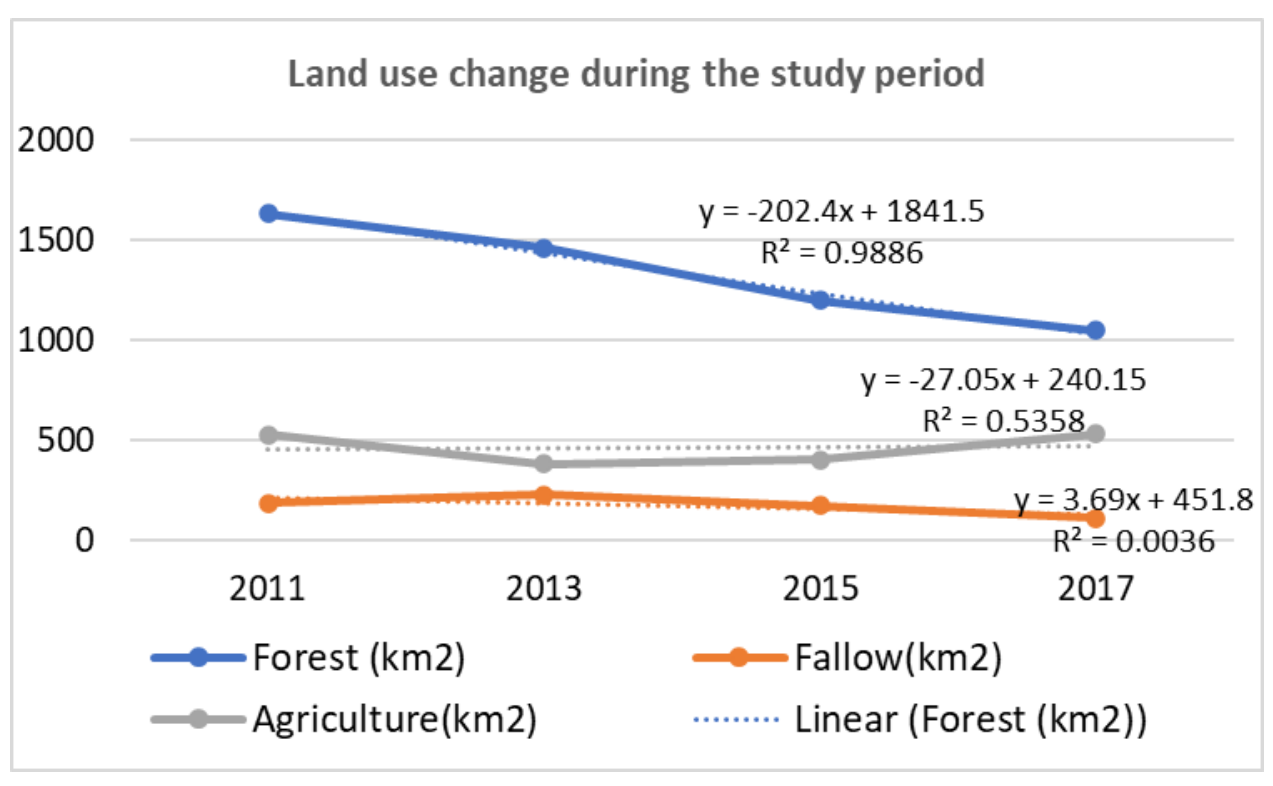

The decrement of forest area during the study period has $r^{2}$ value of 0.9 (Fig.2). Agriculture land area has $\mathrm{r}^{2}$ value of 0.5 and fallow land has $\mathrm{r}^{2}$ value less than 0.1 which is insignificant.

Figure 3 Trend relationship between Fallow land and rainfall \& Fallow land and Temperature with respective years. 




\begin{tabular}{|c|c|c|c|c|c|c|}
\hline Year & \multicolumn{2}{|c|}{$\begin{array}{l}\text { Average } \\
\text { Rainfall(mm) }\end{array}$} & \multicolumn{2}{|c|}{$\begin{array}{l}\text { Mean Max Temperature } \\
\left({ }^{0} \mathrm{C}\right)\end{array}$} & \multicolumn{2}{|c|}{ Fallow $\left(\mathbf{k m}^{2}\right)$} \\
\hline 2011 & \multicolumn{2}{|c|}{201.8} & \multicolumn{2}{|l|}{21.8} & \multicolumn{2}{|l|}{182.3} \\
\hline 2013 & \multicolumn{2}{|c|}{114.3} & \multicolumn{2}{|l|}{21.9} & \multicolumn{2}{|l|}{226} \\
\hline 2015 & \multicolumn{2}{|c|}{180.2} & \multicolumn{2}{|l|}{21.9} & \multicolumn{2}{|l|}{171.5} \\
\hline 2017 & \multicolumn{2}{|c|}{167.2} & \multicolumn{2}{|l|}{22.2} & \multicolumn{2}{|l|}{110.3} \\
\hline \multicolumn{7}{|c|}{ Regression Statistics } \\
\hline & & Coefficients & Standard Error & $t$ Stat & & P-value \\
\hline Fallow area & & 5711.864703 & 181.0359435 & 31.550 & 99806 & 0.020171 \\
\hline $\begin{array}{l}\text { Average } \\
\text { Rainfall(mm) }\end{array}$ & & -0.791601397 & 0.038128561 & -20.76 & 137616 & 0.03064 \\
\hline $\begin{array}{l}\text { Mean } \mathrm{N} \\
\text { Temperature } \\
\text { C) }\end{array}$ & $\begin{array}{r}\operatorname{Max} \\
\left({ }^{0}\right.\end{array}$ & -246.3796274 & 8.194977583 & -30.06 & 771035 & 0.021167 \\
\hline
\end{tabular}


The $r^{2}$ value of maximum mean temperature is 0.8 and it shows significant impact on the area of fallow land use (Fig.3). But the $\mathrm{r}^{2}$ value of rainfall is 0.01 only and it does not have any influence on the land use fallow. The $\mathrm{p}$ value is also less for mean maximum temperature confirming the above results.

Figure 4 Trend relationship between Agricultural land and rainfall \& Agricultural land and Temperature with respective years.

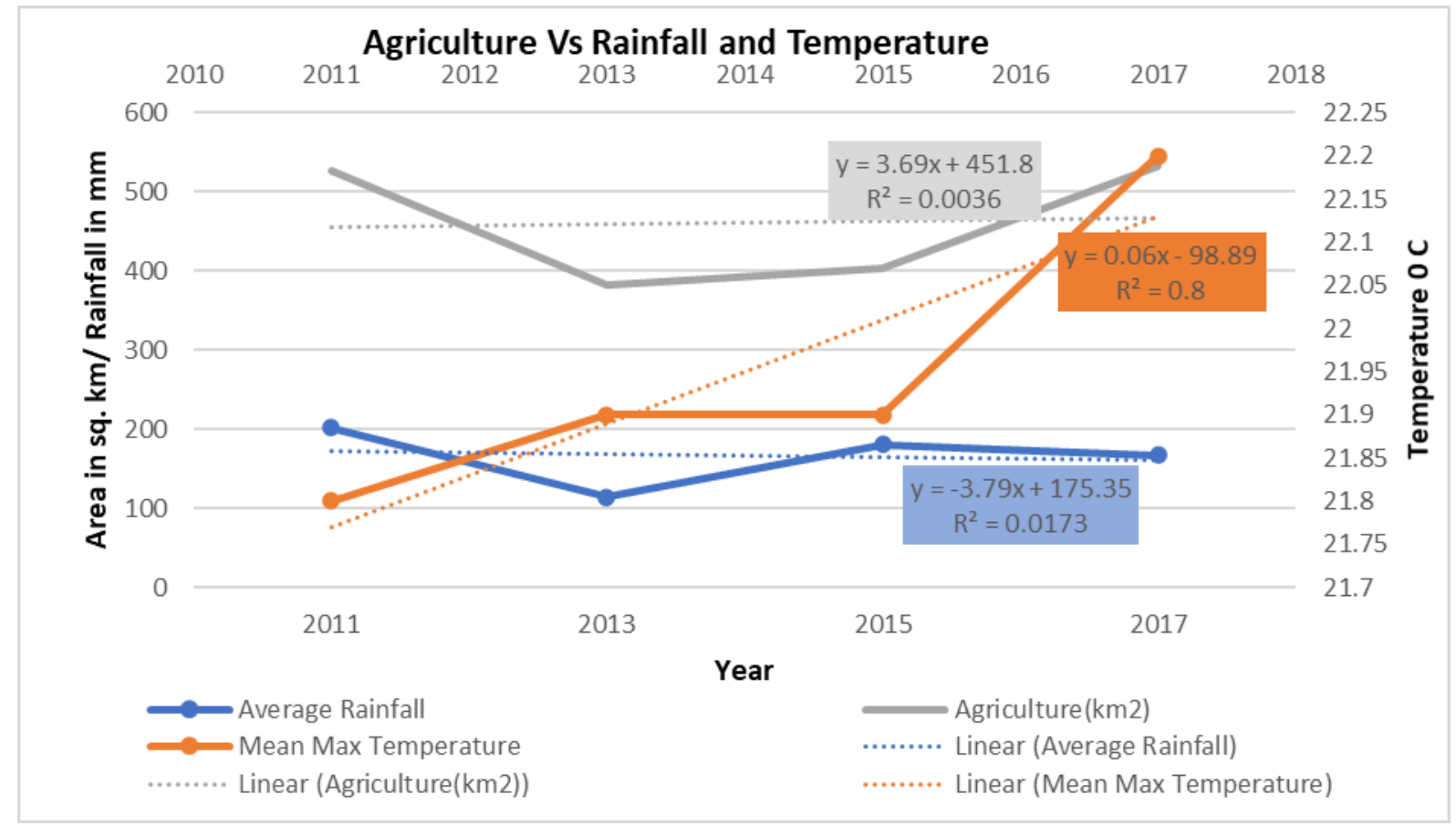

\begin{tabular}{|c|c|c|c|c|c|c|}
\hline Year & $\begin{array}{l}\text { Average Rain } \\
(\mathbf{m m})\end{array}$ & & $\begin{array}{l}\text { Mean M } \\
\left({ }^{0} \mathrm{C}\right)\end{array}$ & Temperature & \multicolumn{2}{|c|}{ Agriculture(km²) } \\
\hline 2011 & \multicolumn{2}{|l|}{201.8} & \multicolumn{2}{|l|}{21.8} & \multicolumn{2}{|l|}{526.9} \\
\hline 2013 & \multicolumn{2}{|l|}{114.3} & \multicolumn{2}{|l|}{21.9} & \multicolumn{2}{|l|}{382.3} \\
\hline 2015 & \multicolumn{2}{|l|}{180.2} & \multicolumn{2}{|l|}{21.9} & \multicolumn{2}{|l|}{402.4} \\
\hline 2017 & \multicolumn{2}{|l|}{167.2} & \multicolumn{2}{|l|}{22.2} & \multicolumn{2}{|l|}{532.5} \\
\hline \multicolumn{4}{|c|}{ Regression Statistics } & & & \\
\hline & & \multicolumn{2}{|c|}{ Coefficients } & $\begin{array}{l}\text { Standard } \\
\text { Error }\end{array}$ & $t$ Stat & $P$-value \\
\hline \multicolumn{2}{|c|}{ Agricultural land $\left(\mathrm{km}^{2}\right)$} & \multicolumn{2}{|c|}{-4612.982155} & 6290.227094 & -0.73336 & 0.597169778 \\
\hline \multicolumn{2}{|c|}{ Average Rainfall (mm) } & \multicolumn{2}{|c|}{1.535327172} & 1.324804912 & 1.158908 & 0.453225454 \\
\hline \multicolumn{2}{|c|}{$\begin{array}{lll}\text { Mean } & \text { Max } & \text { Temperature } \\
\left({ }^{0} \mathrm{C}\right) & & \end{array}$} & \multicolumn{2}{|c|}{219.5596702} & 284.7405273 & 0.771087 & 0.581829519 \\
\hline
\end{tabular}


Since the $\mathrm{r}^{2}$ value of temperature is 0.8 and it seems to have influence on the area of agricultural land. (fig.4). But the rainfall has insignificant effect on the agriculture land use because of very low $r^{2}$ value. The multiple regressing analysis revealed that the $p$ values are very high indicating the agricultural land area is independent of the rainfall and temperature pattern.

Figure 5 Trend relationship between Forest area and Temperature

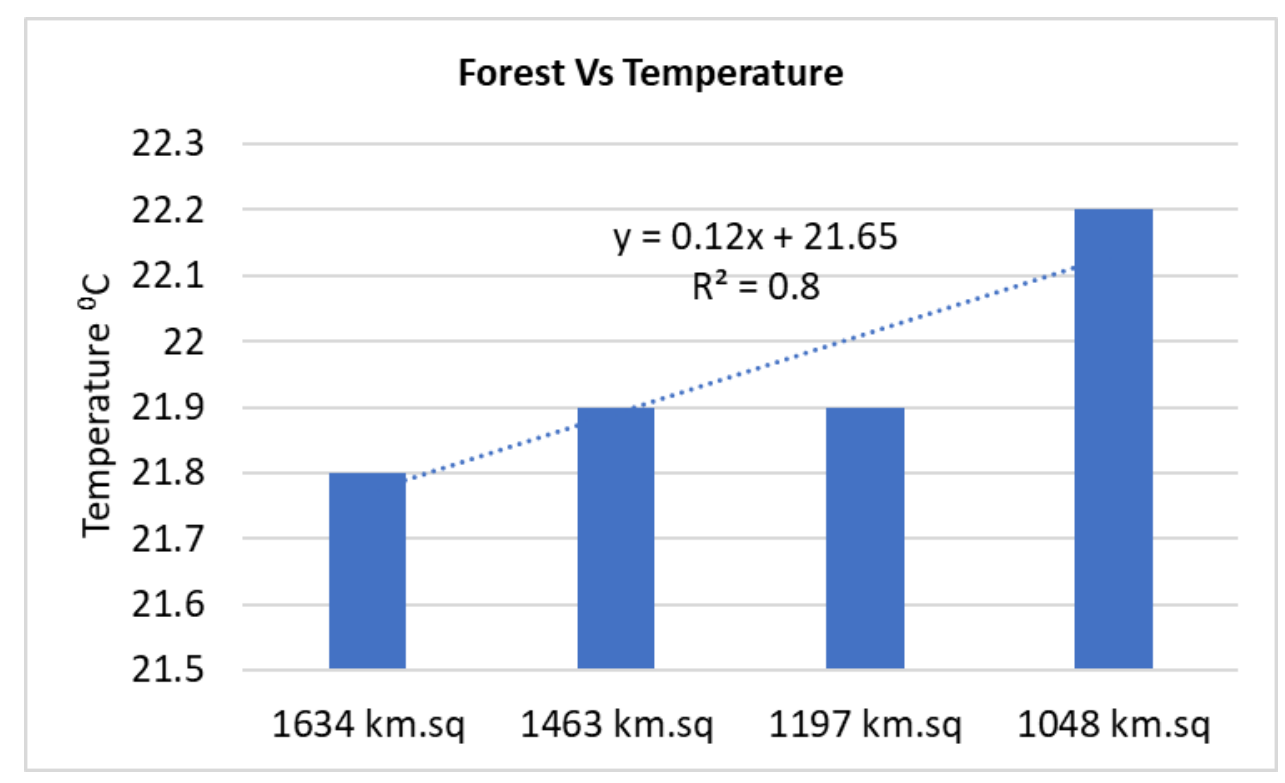

Figure 6 Trend relationship between Forest area and Rainfall

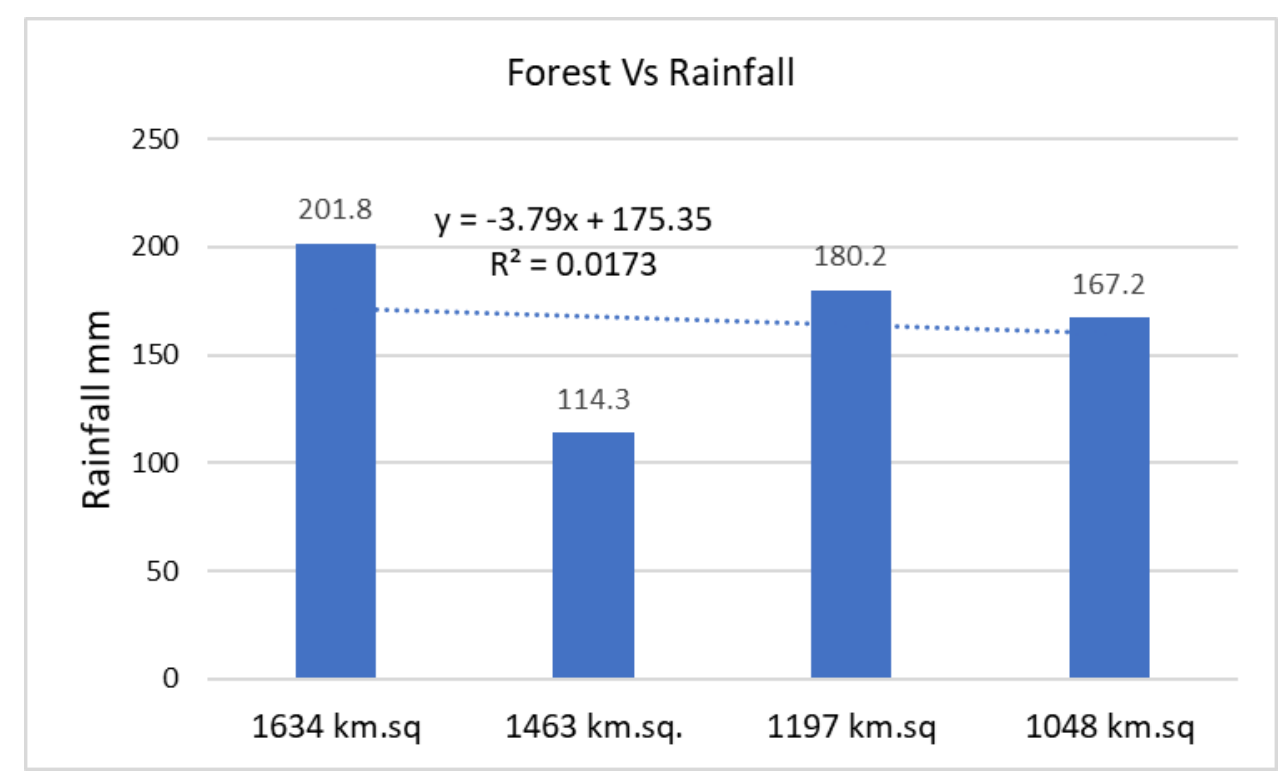






The $\mathrm{r}^{2}$ value is 0.8 for forest area trend with temperature variation indicating the positive trend (Fig.5) whereas the $\mathrm{r}^{2}$ value of forest area with rainfall (Fig.6) is very low indicating no correlation. The multiple regression analysis showed high $\mathrm{p}$ values indicating the independence of Forest area on rainfall and temperature. So it could be concluded that the rainfall and temperature pattern will not influence the forest land area.

\section{CONCLUSION}

The primary aim of this present study was to evaluate the changing land use and climatic parameter of Nilgiris district of Tamil Nadu. It was hypothesized that the land use change of an area is interlinked with the local climate. Therefore, analysis of changes in land use and major climatic parameters were carried out. It was observed that the forest cover and fallow land are decreasing for the study area since 2011, while agricultural land area increasing. Simultaneously, trend analysis of the climatic variables for the period of 2011 to 2017 over the study area revealed that the annual rainfall trend is decreasing whereas, trend of annual maximum temperature is increasing. It should be noted that the present study does not include establishment of a direct relationship between land use change and climatic. Therefore, this present study lays the foundation of a future land use land cover - climate model scenario for testing sensitivity of both climate and land use change to each other. 


\section{REFERENCES}

1. Mishraa, A.K., Singh,V.P. and S. K. Jai. 2010. Impact of global warming and climate change on social development, Journal of Comparative Social Welfare, 26 ( 2-3) : 239-260.

2. Forster, P., Ramaswamy, V., Artaxo, P., Berntsen, T., Betts, R., Fahey, D. W., Haywood, J., Lean, J. L., Lowe, D. C., Myhre, G., Nganga, J., Prinn, R., Raga, G., Schulz, M., and Van Dorland. 2007. 15 R.: Changes in atmospheric Cconstituents and in radiative forcing, in: Climate Change 2007: The Physical Science Basis. Contribution of Working Group I to the Fourth Assessment Report of the Intergovernmental Panel on Climate Change, edited by: Solomon, S., Qin, D., Manning, M., Chen, Z., Marquis, M., Averyt, K. B., Tignor, M., and Miller, H. L., CUP, Cambridge, UK and New York, NY, USA.

3. Shukla, J. and Y. Mintz. 1981. Influence of Land Surface Evapor transpiration on the Earth's Climate, Science, 215: 1498-1501.

4. Stadtmuller, T. 1986. Cloud Forests in the Humid Tropics: distribution and Hydrological Characteristics, Asia Pacific Forest Watershed Newsletter, 9 : 204.

5. Zadroga, F. 1981. The Hydrological Importance of a Montane Cloud Forest Area of Costa Rica, in R. Lal and E.W. Russel (eds), Tropical Agricultural Hydorlogy. J.Wiley, New York, pp. 59-73.

6. Dickinson, R.E. 1980.Effects of Tropical Deforestation on Climate', in Blowing in the Wind: Deforestation and Long-Range Implications, Studies in the Third World Societies, Publ. 14, Dept. of Anthropology, College of William \& Mary, Williamsburg, Va., pp. 411-441. 